\title{
Kinetics Study on Photocatalytic Degradation of Methyl Orange Catalyzed by Sea Urchin-Like $\mathrm{Cu}_{2} \mathrm{O}$
}

\author{
R. J. Gao'1, T. Ding1, X. J. Duan² \\ ${ }^{1}$ Institutes of Materials Science and Engineering, Ocean University of China, Qingdao, China \\ ${ }^{2}$ Zaozhuang Vocational College of Science and Technology, Zaozhuang, China \\ Email:dmh206@126.com
}

Received 22 April 2016; accepted 15 June 2016; published 20 June 2016

\begin{abstract}
Sea urchin-like cuprous oxide with hollow glass microsphere as core was prepared using sodium sulfite as the reducing agent and sodium acetate-acetic acid as buffer solution in copper sulfate solution. Methyl orange was selected as degradation target for photocatalytic experiments. The photocatalytic activities were investigated by visible spectro- photometer. Photocatalytic kinetics parameters were studied by the Langmuir-Hinshelwood model and Arrhenius formula. It was observed that the sea urchin-like morphology dramatically improved the photocatalytic activity of cuprous oxide. The photo-degradation belongs to the first-order reaction and the maximum degradation rate could reach $94.37 \%$. The activation energy and pre-exponential factor are 41.18 $\mathrm{KJ} \cdot \mathrm{mol}^{-1}$ and $1.07 \times 10^{6}$, respectively. After seven times recycling, the sample still showed high photo-catalytic efficiency and stability.
\end{abstract}

\section{Keywords}

Cuprous Oxide, Sea Urchin-Like, Photo-Catalyst, Reaction Kinetic, Methyl Orange

\section{Introduction}

Dye wastewater with the characteristics of complex composition, high color and emissions, high toxicity and poor biodegradability has serious polluted the environment. The common treatment methods of the dye wastewater are flocculation precipitation [1], electrolysis [2], adsorption [3], and biological vectors [4] in industry. One common disadvantage of these methods is that they can transfer the contamination from one phase to another rather than being destructive. Therefore, the invention of a new treatment method without secondary pollution is deemed necessary. In recent years, it has become a focus topic that catalyst is utilized to photodegrade the organic pollutants in wastewater. Cuprous oxide $\left(\mathrm{Cu}_{2} \mathrm{O}\right)$ has a direct band gap of $2.0 \mathrm{eV}$ which can be excited by visible light, and it has high stability in solar cells [5]. In the past decade, $\mathrm{Cu}_{2} \mathrm{O}$ with various morphologies, such as nanosize spheres [6], sea urchin-like [7], porous octahedron [8], nanowires [9] [10], bi-pyramids [11] star-like and flower-like [12], has been synthesized by different techniques. Furthermore, it has 
showed an ideal effect on the photocatalytic degradation organic pollutants in water. However, there are rare reports on the photocatalytic kinetics of $\mathrm{Cu}_{2} \mathrm{O}$ in previous studies.

In this work, the influence of initial methyl orange (MO) concentration on photo-degradation efficiency was studied. Various kinetics parameters including the reaction rate constants, the activation energy, the pre-exponential factor and the reaction order were obtained and the stability property of the sea urchin-like $\mathrm{Cu}_{2} \mathrm{O}$ was also studied.

\section{Experimental}

Preparation and characterization of the sea urchin-like $\mathrm{Cu}_{2} \mathrm{O}$ in detail has been investigated as in [7] and the SEM image of the sea urchin-like $\mathrm{Cu}_{2} \mathrm{O}$ shows in Figure 1. The sea urchin-like $\mathrm{Cu}_{2} \mathrm{O}$ of $0.50 \mathrm{~g} \cdot \mathrm{L}^{-1}$ was added into $\mathrm{MO}$ solutions with different initial concentrations according to the corresponding proportion. Then the system was illuminated under a $24 \mathrm{~W}$ fluorescent lamp (FSL) after the suspension was stirred in darkness for 40 min to ensure adsorption equilibrium. During the reaction, the beaker filled with the suspension was put into a water-bath to maintain the solution at a constant temperature. The distance between the lamp and the solution surface is $15 \mathrm{~cm}$. The suspension was strongly stirred in order to keep the $\mathrm{Cu}_{2} \mathrm{O}$ well suspended in $\mathrm{MO}$ solution. During the course of irradiation, $10 \mathrm{~mL}$ of the suspension was drawn once from the mixture solution every 5 min and filtrated the $\mathrm{Cu}_{2} \mathrm{O}$. The absorbance of $\mathrm{MO}$ aqueous solutions was measured by $7230 \mathrm{G}$ visible spectrophotometer at $464 \mathrm{~nm}$.

\section{Results and Discussion}

\subsection{Effect of Initial MO Concentration on Photodegradation Efficiency}

As shown in Figure 2 the degradation rate of MO first increases and then decreases with the increase of MO concentration from $20 \mathrm{mg} \cdot \mathrm{L}^{-1}$ to $60 \mathrm{mg} \cdot \mathrm{L}^{-1}$. And the degradation rate of $\mathrm{MO}$ after $25 \mathrm{~min}$ reaches $90.9 \%$, 92.23\%, 94.37\%, 91.48\% and 35.35\%, respectively.

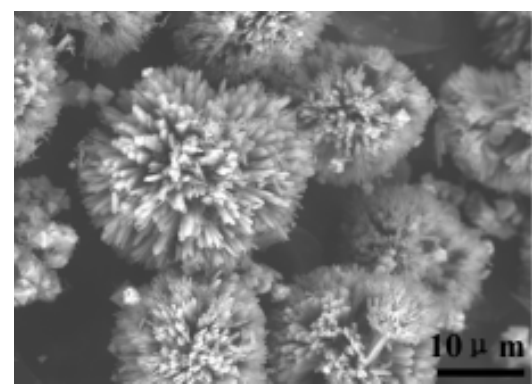

Figure 1. SEM image of the sea urchin-like $\mathrm{Cu}_{2} \mathrm{O}$.

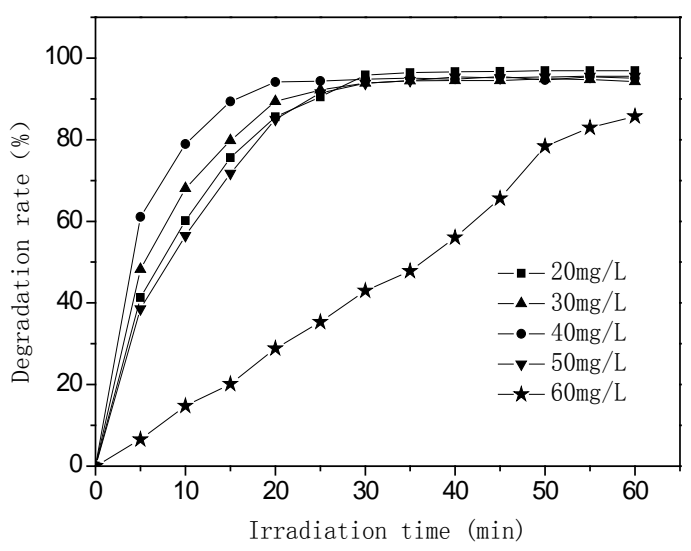

Figure 2. Effect of different initial MO concentration to the degradation rate. 
Compared with diffrent $\mathrm{Cu}_{2} \mathrm{O}$ list in Table 1, sea urchin-like $\mathrm{Cu}_{2} \mathrm{O}$ showed much higher photocatalytic activity due to the three reasons. (a) Needle-like whiskers increase the surface area that determined by BET method is $3.3961 \mathrm{~m}^{2} / \mathrm{g}$. While the BET surface areas of the octahedral morphology and the truncated octahedral morphology are $0.0308 \mathrm{~m}^{2} / \mathrm{g}$ and $0.1819 \mathrm{~m}^{2} / \mathrm{g}$, respectively [13]. (b) The large area exposure of the $\mathrm{Cu}_{2} \mathrm{O}$ whiskers, in which visible light can occur numerous times of reflection and diffuse reflection, augments the adsorption ability and utilization rate of visible light. (c) The width size of crystal whiskers of the sea urchin-like $\mathrm{Cu}_{2} \mathrm{O}$ is only about $100 \mathrm{~nm}$, so $\bullet \mathrm{OH}$ species formed could easily reach the surface of the crystal whiskers to oxidize MO.

\subsection{Reaction Order of the Degradation of MO}

The degradation of $\mathrm{Cu}_{2} \mathrm{O}$ to $\mathrm{MO}$ be supposed to first-order kinetics. So, the previous data (before $20 \mathrm{~min}$ ) taken from Figure 2 were drawn into plots of $-\ln \left(C / C_{0}\right)$ and irradiation time shown in Figure 3 The results reveal that the photo-degradation conform the pseudo first-order kinetics really.

\subsection{The Activation Energy (Ea) and Pre-Exponential Factor (A) of the Sea Urchin-Like $\mathrm{Cu}_{2} \mathrm{O}$}

The temperature can strongly increase the dye degradation, so the activation energy of degredation be studied by the Langmuir-Hinshelwood model [18]. $\mathrm{Cu}_{2} \mathrm{O}+h v \rightarrow e^{-}+h^{+} \mathrm{OH}^{-}+\mathrm{h}^{+} \rightarrow \cdot \mathrm{OH}, \cdot \mathrm{OH}+\mathrm{MO} \stackrel{k_{1}}{\longrightarrow}$ products. The degradation rate of MO be expressed as: $-\frac{d C_{M O}}{d t}=k_{1} C_{\bullet \mathrm{OH}} \cdot C_{\mathrm{MO}}$. If irradiation time and the amount of $\mathrm{Cu}_{2} \mathrm{O}$ are constant, the concentrations of $\bullet \mathrm{OH}$ radicals are also constant, $k=k_{1} C_{\bullet \mathrm{OH}}$, then, $\ln c=-k t+\ln c_{0}$. In Arrhenius formula: $\ln k=\ln A-\frac{E a}{R T}$, where, Ea is activation energy and A is pre-exponential factor. In Arrhenius formula: $\ln k=\ln A-\frac{E a}{R T}$, where, Ea is activation energy and A is pre-exponential factor.

Table 1. The degradation rate of $\mathrm{MO}$ in the presence of different $\mathrm{Cu}_{2} \mathrm{O}$.

\begin{tabular}{|c|c|c|c|c|}
\hline $\mathrm{MO}\left(\mathrm{mg} / \mathrm{L}^{-1}\right)$ & $\mathrm{Cu}_{2} \mathrm{O}\left(\mathrm{mg} \cdot \mathrm{L}^{-1}\right)$ & Time (min) & The degradation rate (\%) & References \\
\hline 40 & 2.00 & 70 & 83.49 & Tang et al. [14] \\
\hline 20 & 0.20 & 420 & 65.5 & Huang et al. [15] \\
\hline 10 & 1.00 & 60 & 62.5 & Zhang et al. [16] \\
\hline 20 & 0.20 & 30 & 37 & Sun et al. [17] \\
\hline 40 & 0.50 & 25 & 94.37 & This work \\
\hline
\end{tabular}

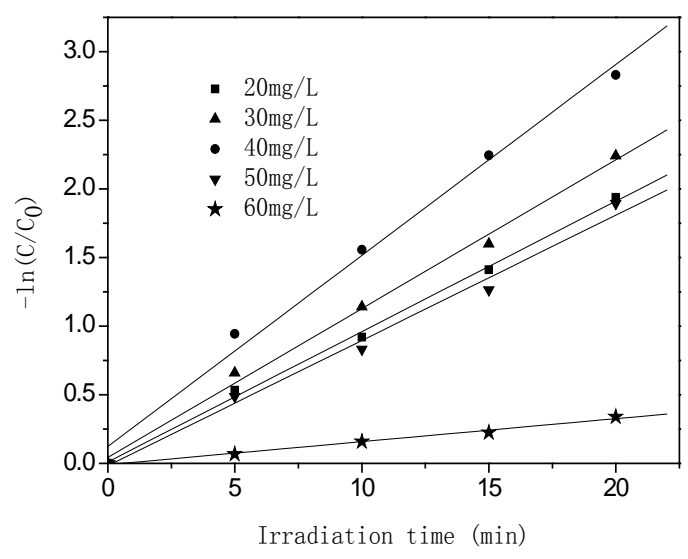

Figure 3. First-order decay curve at different initial MO concentrations. 
Figure 4 shows the results of $\operatorname{lnk}$ at different temperature, $\ln k$ are given as: $\ln k=13.88-\frac{41183.7}{R T}$.

Ea and A of the degradation are $41.18 \mathrm{KJ}^{\mathrm{mol}}{ }^{-1}$ and $1.07 \times 10^{6}$, respectively, with the correlation coefficient of 0.997. Though the raction Ea is little higher than other $\mathrm{Cu}_{2} \mathrm{O}$ samples [13]-[15] [19]-[21], the significant increase of $\mathrm{A}$ also accelerate the reaction, hence the photo-degradation efficiency of $\mathrm{MO}$ is much higher than other $\mathrm{Cu}_{2} \mathrm{O}$ samples [13]-[16].

\subsection{Photo-Catalytic Efficiency of Seven Times Recycling Use of Catalyst}

Stability of $\mathrm{Cu}_{2} \mathrm{O}$ was investigated by reuse 7 times shows in Figure 5 It indicates that the efficiency change from $95.84 \%$ to $76.1 \%$. The $\mathrm{X}$-ray patterns of residual $\mathrm{Cu}_{2} \mathrm{O}$ after the seventh recycled, as shown in Figure 6(b), is same as before use. So, the sea urchin-like $\mathrm{Cu}_{2} \mathrm{O}$ prepared is much stable in the photo-catalysis process under the acidic conditions.

\section{Conclusion}

The sea urchin-like $\mathrm{Cu}_{2} \mathrm{O}$ has highly active to degradation of $\mathrm{MO}$ under visible light irradiation. Degradation rate was achieved to $94.37 \%$ within 25 min. The photo degradation of MO follows the Langmuir-Hinshelwood model and belonging to the first-order reaction. The activation energy and pre-exponential factor are 41.18 $\mathrm{KJ} \cdot \mathrm{mol}^{-1}$ and $1.07 \times 10^{6}$, respectively. After seven times recycling, the $\mathrm{Cu}_{2} \mathrm{O}$ still showed higher photo-catalytic

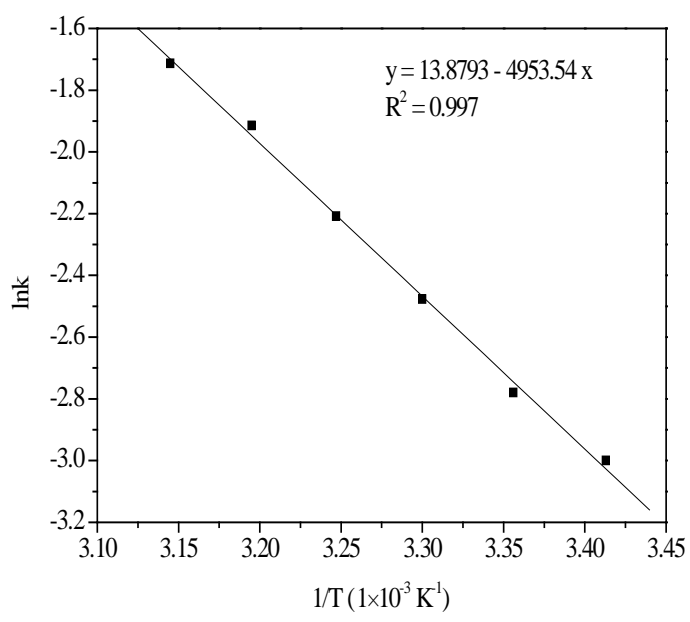

Figure 4. Dependence of the first-order kinetics constant and temperature.

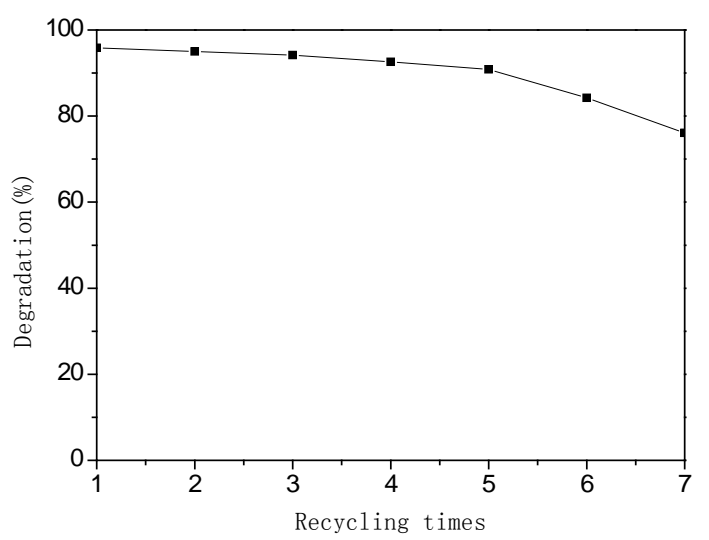

Figure 5. The degradation to $\mathrm{MO}$ of sea urchin-like $\mathrm{Cu}_{2} \mathrm{O}$ photo-catalyst at different reuse times. 


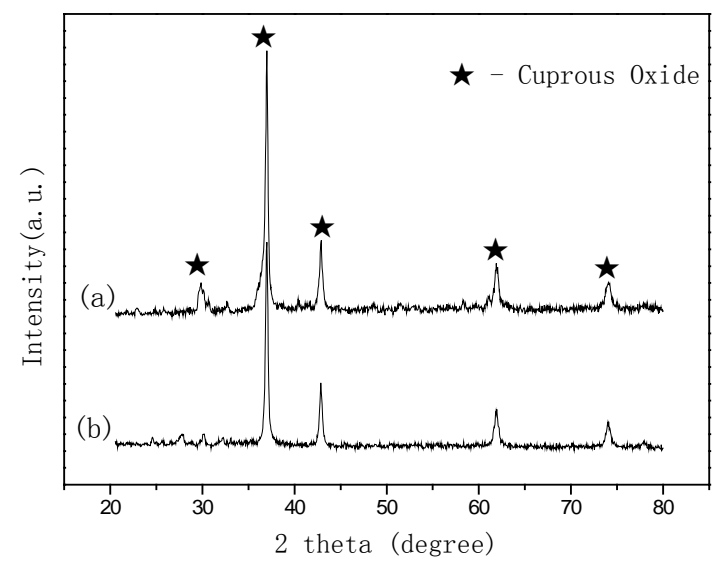

Figure 6. XRD patterns of sea urchin like (a) before use (b) after reuse for seven times.

efficiency and stability.

\section{References}

[1] Golob, V., Vinder, A. and Simonic, M. (2005) Effciency of the Coagulation/Flocculation Method for the Treatment of Dye Bath Effluents. Dyes and Pigments, 67, 93-97. http://dx.doi.org/10.1016/j.dyepig.2004.11.003

[2] Yi, F.Y., Chen, S.X. and Yuan, C.E. (2008) Effect of Activated Carbon Fiber Anode Structure and Electrolysis Conditions on Electrochemical Degradation. Journal of Hazardous Materials, 157, 79-87. http://dx.doi.org/10.1016/j.jhazmat.2007.12.093

[3] Garg, V.K., Amita, M. and Kumar, R. (2004) Basic Dye Removal from Simulated Wastewater by Adsorption Using Indian Rosewood Sawdust. Dyes and Pigments, 63, 243-250. http://dx.doi.org/10.1016/j.dyepig.2004.03.005

[4] Molga, E. and Cherbanski, R. (2006) Modeling of an Industrial Full-Scale Plant for Biological Treatment of Textile Wastewaters: Application of Neural Networks. Industrial \& Engineering Chemistry Research, 45, 1039-1046. http://dx.doi.org/10.1021/ie050699n

[5] Han, K. and Tao, M. (2009) Electrochemically Deposited p-n Homojunction Cuprous Oxide Solar Cells. Solid Energy Material Solid Cells, 93, 153-158. http://dx.doi.org/10.1016/j.solmat.2008.09.023

[6] Bhosale, M.A., Bhatte, K.D. and Bhanage, B.M. (2013) A Rapid, One Pot Microwave Assisted Synthesis of Nanosize Cuprous Oxide. Powder Technology, 235, 515-519. http://dx.doi.org/10.1016/j.powtec.2012.11.006

[7] Duan, X.J., Gao, R.J. and Zhang, Y.D. (2011) Synthesis of Sea Urchin-Like Cuprous Oxide with Hollow Glass Microspheres as Cores and Its Preliminary Application. Materials Letters, 65, 243-250. http://dx.doi.org/10.1016/j.matlet.2011.07.104

[8] Sui, Y.M., Zen, Y. and Fu, L.L. (2013) Low-Temperature Synthesis of Porous hollow Structured $\mathrm{Cu}_{2} \mathrm{O}$ for Photocatalytic Activity and Application. Royal Society Chemistry Advances, 40, 18651-18660.

[9] Duan, X.J., Zhang, Y.D. and Gao, R.J. (2012) Synthesis of 1-D Cuprous Oxide by Using CTAB as a Soft Template in an Acidic System. Materials Letters, 68, 146-148. http://dx.doi.org/10.1016/j.matlet.2011.10.069

[10] Shin, H.S., Song, J.Y. and Yu, J. (2009) Template-Assisted Electrochemical Synthesis of Cuprous Oxide Nanowires. Materials Letters, 63, 397-399. http://dx.doi.org/10.1016/j.matlet.2008.10.052

[11] Jimenez-Cadena, G., Comini, E., Ferroni, M. and Sberveglieri, G. (2010) Synthesis of $\mathrm{Cu}_{2} \mathrm{O}$ Bi-Pyramids by Reduction of $\mathrm{Cu}(\mathrm{OH})_{2}$ in Solution. Materials Letters, 64, 469-472. http://dx.doi.org/10.1016/j.matlet.2009.11.051

[12] Liang, Z.H. and Zhu, Y.J. (2005) Synthesis of Uniformly Sized $\mathrm{Cu}_{2} \mathrm{O}$ Crystals with Star-Like and Flower-Like Morphologies. Materials Letters, 59, 2423-2425. http://dx.doi.org/10.1016/j.matlet.2005.02.086

[13] Yang, H. and Liu, Z.H. (2010) Facile Synthesis, Shape Evolution, and Photocatalytic Activity of Truncated Cuprous Oxide Octahedron Microcrystals with Hollows. Crystal Growth \& Design, 10, 2064-2067.

[14] Tang, A.D., Xiao, Y., Ouyang, J. and Nie, S. (2008) Preparation, Photo-Catalytic Activity of Cuprous Oxide NanoCrystallites with Different Sizes. Journal of Alloys and Compound, 457, 447-451. http://dx.doi.org/10.1016/j.jallcom.2007.02.148

[15] Huang, L., Peng, F., Yu, H. and Wang, H.J. (2009) Preparation of Cuprous Oxides with Different Sizes and Their 
Behaviors of Adsorption, Visible-Light Driven Photocatalysis. Solid State Sciences, 11, 129-138. http://dx.doi.org/10.1016/j.solidstatesciences.2008.04.013

[16] Zhang, X.X., Song, J.M., Jiao, J. and Me, X.F. (2010) Preparation and Photocatalytic Activity of Cuprous Oxides. Solid State Sciences, 12, 1215-1219. http://dx.doi.org/10.1016/j.solidstatesciences.2010.03.009

[17] Sun, W., Sun, W.D. and Zhuo, Y.J. (2011) Facile Synthesis of $\mathrm{Cu}_{2} \mathrm{O}$ Nanocube/Polycarbazole Compositesand Their High Visible-Light Photocatalytic Properties. Journal of Hazardous Material, 184, 1628-1643. http://dx.doi.org/10.1016/j.jssc.2011.03.055

[18] Yang, H. and Liu, Z.H. (2010) Facile Synthesis, Shape Evolution, and Photocatalytic Activity of Truncated Cuprous Oxide Octahedron Microcrystals with Hollows. CrystalGrowth\& Design, 10, 2064-2067.

[19] Leghari Sajjad, A.K., Shamaila, S. and Tian, B.Z. (2010) Comparative Studies of Operational Parameters of Degradation of Azo Dyes Invisible Light. Journal of Hazardous Material, 177, 781-786.

[20] Tang, D.P., Yuan, R. and Chai, Y.Q. (2006) Ligand-functionalized core/shell Ag@Au nanoparticles labelfree amperometric immunbiosensor. Biotechnology and Bioengineering, 94, 996-1004. http://dx.doi.org/10.1002/bit.20922

[21] Kim, J.Y., Rodriguez, J.A. and Hanson, J.C. (2003) Reduction of $\mathrm{CuO}$ and $\mathrm{Cu}_{2} \mathrm{O}$ with $\mathrm{H}_{2}: \mathrm{H}$ Embedding and Kinetic Effectsinthe Formation of Suboxides. The Journal American Chemical Society, 125, 10684-10692. http://dx.doi.org/10.1021/ja0301673 